\title{
10.53116/pgaflr.2018.2.3 \\ The Amendment of the Religious Registration Law and Its Impact on Freedom of Religion in the Slovak Republic
}

\author{
Mária Havelková* \\ * Mária Havelková, JUDr., postgraduate student, Comenius University in Bratislava, Faculty of Law, \\ Department of Administrative and Environmental Law, Slovakia. (e-mail: maria.havelkova@flaw. \\ uniba.sk)
}

\begin{abstract}
Church registration represents a legitimate instrument of surveillance over religious groups. In the Slovak Republic, registered churches are funded directly out of the State budget and dispose of a wide range of other financial, as well as non-financial benefits. Slovakia has recently tightened up the already strict registration criterion of a number of supporters. According to the currently effective legislation, a church or religious society applying for registration must provide evidence of having over 50,000 members. The main aim of this article is to analyse the impact of the new Slovak legislation on the freedom of religion with a focus on assessment of whether the range of rights and duties for registered churches are the same as for not registered ones and whether this measure is in conformity with human rights standards applied in the European Union, as well as the Council of Europe.
\end{abstract}

Keywords: freedom of religion; registration of churches; church funding; discrimination of minority religions

\section{Introduction}

Increasing religious diversity within societies all around the Globe cannot be overlooked. This phenomenon is mainly caused by migration of ethnic and religious groups seeking better opportunities or fleeing persecution or war in their home countries. ${ }^{2}$

Given the growth of religious diversity, state authorities have the power to evaluate religious groups in order to determine if they should be allowed to function. The control of religion is justified in terms of securing peaceful coexistence of different religious groups. Church registration is the most frequent method of surveillance over the religious groups and its implementation is increasing. ${ }^{3}$ Notwithstanding the power of the State to control churches and religious societies, the State is still obliged to create such a system of StateChurch law which allows a maximum degree of religious freedom and autonomy. ${ }^{4}$

From a bureaucratic point of view, the Church registration represents administrative proceeding carried out by the State authorities. Even though the main purpose is control of religious societies and protection of citizens, church registration is closely linked to financial interests of the State. The Slovak Republic is one of several European countries in which registered Churches and religious societies are funded directly out of the State budget. 
Financing of Churches out of public funds have always been a topic in Slovakia. However, this is only one of many financial and other benefits resulting from successful registration.

The Slovak Republic (hereinafter referred to as the SR) has recently tightened up the already strict registration criterion of a number of supporters. According to the currently effective legislation, a church or religious society applying for registration must provide evidence of having 50,000 members.

Therefore, the aim of this paper is to analyse the impact of the new Slovak legislation on the freedom of religion with a focus on assessment of whether the range of rights and duties for registered churches are the same as for not registered ones and whether this measure is in conformity with the European human rights protection instruments.

\section{The Role of Religion in the Slovak Republic}

Religion has always played an important role on the territory of the SR. The Slovak Constitution acknowledges in its Preamble the spiritual heritage of Cyril and Methodius and in its Article 1 the basic principle is to be found: "The Slovak Republic is a sovereign, democratic state governed by the rule of law. It is not bound by any ideology or religion." Freedom of religion is one of the fundamental freedoms guaranteed in Article 24 of the Slovak Constitution. This Article contains not only the individual freedom of religion including the freedom from religion and the right to change religion freely but also the collective expression of the freedom of religion. Religious faith as an individual right (forum internum) and as such, it is inalienable and inviolable and therefore, not subject to any legal restrain. In other words, the internal dimension of freedom of religion is absolutely protected. 5 On the other hand, public expressions of religious affiliation as a collective right (forum externum) and may be subject to limitation under certain circumstances. The freedom to manifest one's religion may be limited if it is necessary in a democratic society for the protection of public order, health and morals or for the protection of the rights and freedoms of others. ${ }^{6}$

The status of Churches and religious societies (hereinafter referred to as Churches) is provided by Act No. 308/1991 Coll. on the freedom of belief and the position of churches and religious societies (hereinafter referred to as the Act). Under the Act, Churches are voluntary associations of persons of the same belief in organizations with their own structure, bodies and internal regulations. ${ }^{7}$ The State recognised only Churches that are registered by the registration body, i.e. the Ministry of Culture of the SR. A registered Church is a legal entity taking advantage of a special status and also other rights awarded to all legal entities. ${ }^{8}$ Even though the SR proclaims to be a secular state, the Roman-Catholic Church has a strong position arising from the fact that more than $62 \%$ of the citizens confess to this Church.' An important highlight in the Slovak church policy was the adoption of the Basic Treaty between the Holy See and the SR in 2000. The treaty with the Vatican had far-reaching implications when enacted various responsibilities for the SR, e.g. obligations such as:

a) to subsidise the Catholic church from the State budget

b) to accept conscientious objection ${ }^{10}$ 
c) to accept the right of the Church to establish Catholic schools

d) to guarantee ten Catholic feast days to be accounted as national holidays

e) to accept pastoral activities in armed and police forces as well as in penitentiary facilities

All this confirmed the privileged position of the Roman-Catholic Church. Although similar agreements were signed with most of the registered Churches in 2002, they simply used the agreement with the Holy See as a template. ${ }^{11}$

The Roman-Catholic Church has a considerable influence on public, as well as political affairs. One example will suffice: During the pre-election period in 2012, the Bishop's Conference held a consultation with the most influential political parties and presented a series of requirements the Roman-Catholic Church wanted parties to meet. These include the prohibition of abortion, further "protection" of heterosexual marriages ${ }^{12}$ and the guarantee of Sunday rest. ${ }^{13}$

\section{The Legal Background of Religious Registration Processes}

As was already mentioned above, the Slovak Republic recognises only Churches that are registered by the Ministry of Culture. The Act sets a number of positive and negative prerequisites which need to be met cumulatively. Under the legislation currently in force positive preconditions are:

a) registration proposal submitted by a preparatory Committee

b) fundamental characteristics of the establishing Church

c) a statement that the Church will fully respect Slovak laws and will be tolerant to other Churches, as well as to persons without a confession

d) affidavits of at least 50,000 adult citizens of the SR with the right of permanent residence attesting to the membership and support for registration of their church including their names, surnames, permanent address and their personal identity numbers

The Act also provides negative prerequisites preventing the establishment of the Church which are enshrined within Article 15 of the Act. The Church shall not be registered if its establishment and activity:

a) is not in compliance with:

1. the Act and Slovak legislation in general

2. the protection of citizens' safety, health, morality and public order

3. principles of humanity and tolerance

b) threatens the rights of other legal entities or individuals

In the following text, we will focus more closely on the positive prerequisites requiring solemn declarations of at least 50,000 members. The quantitative registration rule has been tightened repeatedly during the short existence of the SR, as last in May 2017 when the number of members has been increased from 20,000 to 50,000. 
However, this rule has always been very strict considering the Slovak population of only about 5.4 million people. Firstly, the condition was 20,000 followers with permanent residence in the $S R$.

Subsequently, in 2007 the Slovak Parliament adopted an even stricter law, which required churches seeking registration to have 20,000 citizens domiciled in the $S R$, who submit an affidavit attesting to the membership and support for registration of their church and disclosing sensitive personal data, such as their personal identity number and home address.

It follows that even before the amendment of the Act in March 2017, Slovakia had already had the strictest registration requirements in the European Union and possibly even among all 57 participants countries of the OSCE. ${ }^{14}$ Further, according to P. Mulík, the 20,000 followers registration criterion had been "among the most restrictive of any democratic state in the entire world". ${ }^{15}$ Moreover, based on the 2011 census, only four currently registered groups meet the new member requirement, and half of the currently registered churches and religious societies have fewer than 5,000 members. ${ }^{16}$

On the basis of the above said arises an unavoidable question of the reasons for the passing of an even stricter law which prescribes that religious groups seeking government recognition must provide evidence of having 50,000 adult members with Slovak citizenship. Some members of Parliament proposed even higher criteria, specifically 250,000 members for an aspiring community. This was supported by only 26 out of the 150 parliamentarians, hence it did not pass.

Incentives and reasons for adoption of the law shall be in general enshrined within an explanatory report. However, in this case the explanatory report is disproportionately brief and the declared justification for the new registration law is contained in only one sentence, which stated that the policy "eliminates speculative registrations that could manipulate the state for financial benefits". Even though explanatory reports cannot be considered a source of law, ${ }^{17}$ it is an important instrument for justification and rationale of any amendment of legislation. Although in this case, the explanatory report is missing any relevant reasoning which calls into question the legitimacy of the new legislation.

As was mentioned by the President of the SR Andrej Kiska, who unsuccessfully vetoed the act in question, the explanatory report does not state why this measure was necessary, as well as reasons why the existing legislation has become insufficient.

On the basis of the above, we believe that it is a purely political decision reflecting the current emotional atmosphere in the Slovak society. It implies a strong anti-Islamic narrative. This is evident from the straightforward statements of the state leaders. The same day when the law was adopted, the President of the Slovak Parliament stated, that "Islamisation starts with a kebab and it's already underway in Bratislava, let's realise what we can face in 5 to 10 years. [...] We must do everything we can so that no mosque is built in the future".

In this context, the attention should be drawn to the important fact that since 2007 , i.e. since the registration criteria were strengthened for the first time, not a single religious community has been able to register. ${ }^{18}$ 


\section{The Importance of Accessible Religious Registration}

After the first religious registration amendment was passed in 2007, the General Prosecutor questioned the legality of the new law and filed a petition to the Constitutional Court of the SR. However, the Constitutional Court held, that "Registration of the Church or religious society is not an inevitable condition for the exercise of religious freedom. Registration only concerns their existence as a state-recognized Church or religious society and has a legal relevance only from the economic point of view" ${ }^{19}$ We strongly disagree with this ruling on the grounds presented below.

The Church registration does not only represent a control mechanism. Registered Churches dispose of a wide range of diverse benefits and rights. The advantages of registration are significant and we can distinguish between economic and non-economic benefits.

\subsection{Non-economic benefits of Church registration}

First and foremost, churches require legal subjectivity, which enables them to function as a legal entity. All of their internal affairs are conducted free from the interference of the government, e.g. they have their own structure and internal bodies, they may appoint their own representatives, they may own their own property and they may issue and enforce internal rules and regulations without the approval of the State. ${ }^{20}$

Registered Churches have an authority to influence different spheres of citizens' everyday life by establishing their own primary and secondary schools, universities and educational institutions ${ }^{21}$ engage in printing and publishing activities and own and operate cultural, medical and social service facilities. The clergy of registered churches can perform State recognised wedding ceremonies ${ }^{22}$ and pastoral activities in healthcare facilities, orphanages and child care facilities, armed and police forces, as well as in penitentiary facilities.

\subsection{Financial benefits of Church registration}

Under Act no. 218/1949 Coll. on the economic security of Churches and religious societies by the State, all registered Churches are eligible for financial support from the State budget according to the number of the Church clergy. In 2018 over $42.5 \mathrm{~m}$ Euros have been reallocated among 18 currently registered Churches. ${ }^{23}$ During communism, an extensive amount of property of the Church has been nationalised. Despite the restitution in the early 1990s, the State is not able to return all nationalised property since most of this property is serving military and public purposes. According to M. Moravčíková, this is "one of the reasons of preferring the preservation of the old system of financing from the State budget.". 24

Except direct economic support, registered Churches also enjoy exemptions from various taxes, such as value-added tax, land tax, inheritance tax and property tax. In addition, religious objects and gifts for churches are exempt from import duty. ${ }^{25}$ Churches may 
apply for social, charitable or cultural projects, as well as for grants towards the preservation and recovery of cultural landmarks. ${ }^{26}$

Unregistered churches are not able to benefit from any of the aforementioned rights and privileges. It is clear that obtaining a legal recognition is both practical and vital and that state funding and certain privileges (e.g. tax exemptions) drastically impact the religious groups' ability to function. ${ }^{27}$

One may argue that unregistered religious groups are generally able to function in spite of these obstacles and can register as civil associations or foundations. However, the Act on Citizens' Associations is inapplicable to citizens' associations in Churches or religious societies and under Article 12, the Ministry of the Interior shall dissolve an association if it is engaged in activities reserved to Churches. Even though, such associations ${ }^{28}$ are currently tolerated by the State authorities, nevertheless, they are under a constant threat that they could be dissolved practically at any time.

Therefore, we can conclude that the range of rights and duties is not the same and minority religions are discriminated in the $S R$.

\section{Assessment of the Amendment with Regards to European Human Rights Standards}

The prevailing opinion among lawyers affirms that the number of faithful of a religious group should not constitute an obstacle to getting its legal personality and the required number should be proportionate and adequate. ${ }^{29}$

Asma Jahangir, the UN' Special Rapporteur on Freedom of Religion and Belief, in his 2004 annual report stated that "registration appeared often to be used as a means to limit the right of freedom of religion or belief of members of certain religious communities". She also added, that "registration procedures should be easy and quick and not depend on extensive formal requirements in terms of the number of members..." ${ }^{30}$

Last but not least, back in 1993 the Human Right Committee stated that "The Committee views with concern any tendency to discriminate against any religion or belief for any reason, including the fact that they are newly established, or represent religious minorities." 31

In order to have a more precise picture, it is appropriate to have a closer look at different numerical requirements for religious organizations across the European countries in which the registration system is applied. In a number of European States less than 100 individuals may form a Church or religious association; 10 in Ukraine, 12 in Estonia, 20 in Finland and Belarus and 30 in Austria. The prerequisite of 100 members is applied in Poland and Serbia. In Greece the number is slightly higher - 300 members and 500 members is the condition applied in Croatia. There are also countries with different numerical prerequisites for so-called traditional and non-traditional religions. For example, in Denmark in order for a religious community to be registered, it must have at least 150 members, while a congregation, which the Ministry of Culture and Ecclesiastic Affairs considers a group within one of the major world religions (Christianity, Judaism, 
Hinduism, Buddhism and Islam), must consist of at least 50 adult members to be approved. The two-tier system is well established in the Czech Republic and Romania. Except for Slovakia, the highest numerical requirement is applied in Hungary (1,000 individuals in case of a non-tradition religion) and Sweden (3,000 persons). ${ }^{32}$

In this context, the new amendment of the Slovak law is clearly unfounded (the highest numerical census between all EU and Council of Europe member states), unnecessary (due to the fact that not a single religious group had been registered after the last amendment in 2007), inappropriate, discriminatory against minority religions and therefore in conflict with European human rights standards.

On these grounds, we presume that in case of an application to the European Court of Human Rights (hereinafter referred to as ECtHR), there is a high possibility that the Court will state the breach of relevant European Convention articles. In support of his statement, the ECtHR held relatively recently, that "even where legislation expressly authorises the operation of unregistered religious groups, that is insufficient if domestic law reserves a whole series of rights essential for conducting religious activities (exclusively) for registered organisations with legal personality." ${ }^{3}$

As a possible solution, we suggest the creation of a two-step registration model. The legislation of the Czech Republic can serve as an inspiring model. In the first step, the signatures of 300 adult adherents with permanent residence is necessary for a state registration. ${ }^{34}$ In order to be eligible for the wider scope of rights, e.g. benefiting from State subsidies and performing marriage ceremonies with civil effects, a Church needs to have been registered without interruption for a minimum of 10 years and an application has to include signatures of citizens of the Czech Republic or foreigners residing there permanently; their number has to be equal or superior to at least 1/1,000 of the entire Czech population (approximately 10,700 individuals). ${ }^{35}$ Admissibility of this model has been already accepted by the ECtHR. ${ }^{36}$

From all of what has already been mentioned is evident that the problem is much more complex and a proposed solution would not resolve the general negative attitude in the Slovak society, as well as the inappropriate approach of politicians. State representatives should set a good example; however, most of them only adopt this unacceptable approach to minority religions and in fact to minorities in general.

As it has been said by L. M. Ondrasek, "the principal resolution should be primarily in education and dialogue on religious issues that lead to the development of critical thinking and thus to informed conclusions." ${ }^{37}$

\section{Conclusions}

Church registration represents the most frequent method of surveillance over religious groups. In the Slovak Republic, the registered Churches are funded by the State budget and dispose of a wide range of other financial, as well as non-financial benefits. Therefore, the registration process and its preconditions are closely linked to financial interests of the State. 
Church registration is a legitimate instrument for the protection of State interests, as well as rights and freedoms of individuals. However, the requirements of the registration process have to be clear and predictable and they need to be met realistically. ${ }^{38}$ According to the primary objective of this article, it is evident that the recently amended numerical prerequisite is inappropriate, discriminatory against minority religions and inconsistent with the current case law of the ECtHR. It has been demonstrated that the positive precondition of 50,000 members with Slovak citizenship and the right to permanent residence is clearly the highest numerical census between all EU and Council of Europe member states. Since not a single religious group had been registered after the last amendment in 2007, the new legislation is unnecessary and unjustified.

The control of religious groups should always lead to the maintenance of peaceful coexistence and the protection of potential members against intimidation, abuse and authoritative approach of the clergy. A democratic and legal State shall not discriminate ancient traditional religions. However, in the Slovak Republic there is no possibility for religions such as Buddhism, Hinduism and Islam to register. 


\section{References}

1 The article was supported by the Grant of Comenius University to foster scientific, pedagogical and cultural projects of young teachers, research associates and internal PhD students, no. UK/100/2018 „Právna úprava registrácie cirkvi a náboženských spoločností a jej vplyv na slobodu vierovyznania."

2 James T. Richardson, Managing Religion and the Judicialization of Religious Freedom, 2, in Journal of the Scientific Study of Religion, vol. 54, no. 1 (2015), https://onlinelibrary.wiley.com/doi/abs/10.1111/ jssr.12172 (accessed 28 May 2018). https://doi.org/10.1111/jssr.12172

3 Roger Finke, Dane R. Mataic, Jonathan Fox, Exploring the Trends and Consequences of Religious Registration: A Global Overview, www.thearda.com/rrh/papers/registration.asp (accessed 2 May 2018).

4 Michaela Moravč́ková, The question of secular state, recognition of religious subjects and their economical support, 374, in Vestnik SPbSU. Philosophy and Conflict studies, vol. 33, no. 3 (2017). https://doi.org/10.21638/11701/

5 Neil Foster, Freedom of Religion and Balancing Clauses in Discrimination Legislation, 38617 , in 313 ford Journal of Law and Religion, vol. 5, no. 3 (2016). https://doi.org/10.1093/ojlr/rww045

6 Martin Dojčár, The Religious Freedom and Legal Status of Churches, Religious Organizations, and New Religious Movements in the Slovak Republic, 430, in Brigham Young University Law Review, vol. 2 (2001).

7 Art. 4 par. 1 of the Act.

8 Moravč́ková, supra n. 4, at 375.

9 The data are available at: https://census2011.statistics.sk/tabulky.html (accessed 28 May 2018).

10 This is affecting issues such as euthanasia, abortion etc.

11 Miroslav Tížik, Secularization of Public Life and Desecularization of the State, 163, in Jan Nelis (ed.), Religion and Secularism in the European Union (Brussels, P.I.E. Peter Lang, 2017).

12 In September 2014 the Constitution was amended and Article 41 has been supplemented by the following provision: "Marriage is a unique bond between man and woman."

13 Tížik, supra n. 11, at 165.

14 Lubomír M. Ondrasek, Slovakia’s New Religious Registration Law is a Step in the Wrong Direction, in Providence. A Journal of Christianity \& American Foreign Policy, 1 March 2017, https://providencemag. com/2017/03/slovakias-new-religious-registration-law-step-wrong-direction/ (accessed 9 May 2018).

15 Peter Mulík, Church and State in Slovakia, 320, in Silvio Ferrari, Cole W. Durham (ed.), Law and Religion in Post-Communist Europe (Leuven, Peeters, 2003).

16 L'ubomír M. Ondrasek, Slovakia's New Religious Registration Law is a Step in the Wrong Direction. In Providence. A Journal of Christianity \& American Foreign Policy, 1 March 2017, https://providencemag. com/2017/03/slovakias-new-religious-registration-law-step-wrong-direction/ (accessed 9 May 2018).

17 Judgement of the Supreme Court of the Slovak Republic, No. 10Sžo/80/2015, 25 May 2016.

18 Shortly before this first amendment came into the force, the Religious Society of Jehovah's Witnesses, the Church of Jesus Christ of Latter-day Saints, and the Baha'i Faith had been registered.

19 Finding of the Constitutional Court of the Slovak Republic, No. PL. ÚS 10/08-70, February 3, 2010.

20 Martin Dojčár, The Religious Freedom and Legal Status of Churches, Religious Organizations, and New Religious Movements in the Slovak Republic, 432, in Brigham Young University Law Review, vol. 26 (2001).

21 Salaries and training of teachers of religious courses are covered by public funds. In 2015 religious teachers represented 15\% of all teachers. For details please see Tížik, supra n. 11, at 164.

22 Lubomír M. Ondrasek, On Religious Freedom in the Slovak Republic, 1-9, in Occasional Papers on Religion in Eastern Europe, vol. 29, no. 3 (2009).

23 Almost $27 \mathrm{~m}$ Euros have been assigned to the Roman-Catholic Church and only 8,300 Euros have been allocated to the New Apostolic Church. Four Churches including the Religious Society of Jehovah's Witnesses did not apply for State support.

24 Moravčíková, supra n. 4, 378-379.

25 Michaela Moravč́ková, Religion, Law, and Secular Principles in the Slovak Republic, 623, www. strasbourgconsortium.org/content/blurb/files/Slovakia.1.pdf (accessed 9 May 2018). 
26 Moravč́ková, supra n. 4, at 378.

27 Jeroen Temperman, Recognition, Registration and Autonomy of Religious Groups: European Approaches and their Human Rights Implications, 153, in David M. Kirkham (ed.), State Responses to Religious Minorities (Aldershot, Ashgate, 2013).

28 Such as the Muslim Slovak Association.

29 Silvio Ferrari, Registration of Religious Organizations in the European Union Member States, 4, in Stato, Chiese e pluralismo confessionale, 2007, https://riviste.unimi.it/index.php/statoechiese/article/view/881/ 1124 (accessed 8 October 2017). https://doi.org/10.13130/1971-8543/881

30 Report submitted by Asma Jahangir, Special Rapporteur on freedom of religion or belief. No. E/ CN.4/2005/61, 20 December 2004, https://documents-dds-ny.un.org/doc/UNDO C/GEN/G05/101/ 50/PDF/G0510150.pdf?OpenElement (accessed 2 October 2017).

31 General Comment No. 22: Article 18, adopted at the $48^{\text {th }}$ Session of the Human Rights Committee, on 30 July 1993, par. 2.

32 International Religious Freedom Report for 2017. The US Bureau of Democracy, Human Rights and Labour, www.state.gov/j/drl/rls/irf/religiousfreedom/index.htm?d\#wrapper (accessed 8 June 2018).

33 Sviato-Mykhailivska Parafiya v. Ukraine, 77703/01, 14 June 2007 \$ 122.

34 At this level a registered church has a status of legal entity and certain rights, such as the right to educate their clergy in their own schools and institutions.

35 Roman Vido, The Czech Republic. New Challenges for Churches in a Highly Secularized Society, 46, in Jan Nelis (ed.), Religion and Secularism in the European Union (Brussels, P.I.E. Peter Lang, 2017).

36 For details please see Lajda and Others v. the Czech Republic, Case No. 20984/05, 3 March 2009 or Kimlya and Others v. Russia, Applications Nos. 76836/01 and 32782/03, 1 October $2009 \S 84$.

37 Ondrasek, supra n. 22, at 6.

38 Renáta Uitz, Hungary's New Constitution and Its New Law on Freedom of Religion and Churches: The Return of the Sovereign, 963, in Brigham Young University Law Review, vol. 37, no. 3 (2012). 